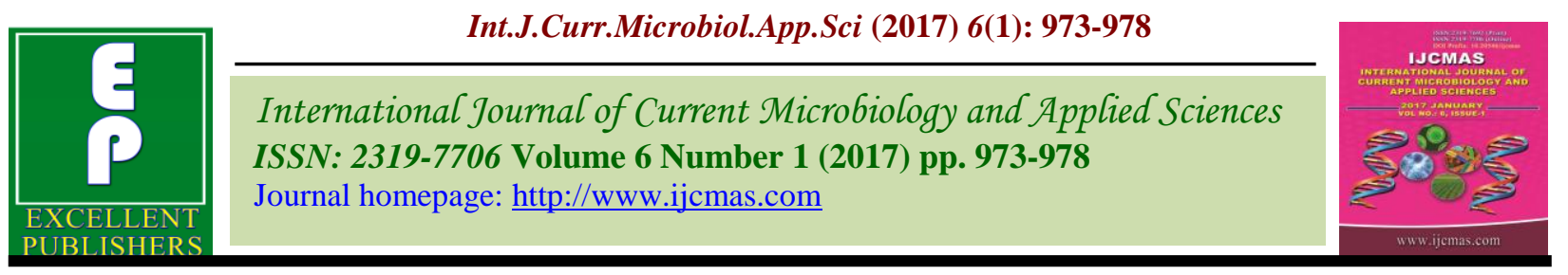

Original Research Article

http://dx.doi.org/10.20546/ijcmas.2017.601.115

\title{
Gut Enzyme Activities of the Earthworm, Perionyx ceylanensis Collected from Different Vermibed Substrates
}

\author{
J. Devi ${ }^{1}$ and M. Prakash ${ }^{2 *}$ \\ ${ }^{1}$ Research \& Development Centre, Bharathiar University, \\ Coimbatore-641 046, Tamil Nadu, India \\ ${ }^{2}$ Department of Microbiology, Kanchi Shri Krishna College of Arts and Science, \\ Kilambi, Kancheepuram-631 551, Tamil Nadu, India \\ *Corresponding author
}

\begin{abstract}
A B S T R A C T
Keywords

Enzyme activity,

Earthworm gut, Stages

of earthworms,

Vermibed substrates

Article Info

Accepted:

09 December 2016

Available Online:

10 January 2017

Enzymes in the gut of three different stages (juvenile, pre-clitellate, clitellate) of the earthworm species Perionyx ceylanensis, reared in the vermibed substrates namely, teak leaf litter (TLL), paper mill sludge (PMS) and pressmud (PM) in combination with cowdung were analysed. The enzymes, amylase (EC 3.2.1.1), cellulase (EC 3.2.1.4.), protease (EC 3.4.0), phosphatase (EC 3.1.3.1, 2) and invertase (EC 3.2.1.20) were analysed from gut contents of the earthworm reared in TLL, PMS and PM on $60^{\text {th }}$ day. The activity of the enzymes amylase, cellulase, protease, phosphatase and invertase were invariably observed to be more in clitellate adults followed by pre-clitellates and juveniles. The results also showed variation in enzyme activities with respect to different vermibed substrates.
\end{abstract}

\section{Introduction}

Disposal of solid waste has become a major problem recently due to shortage of dumping sites and strict environmental laws. As a result emphasis is now on aerobic composting, defined as a microbiological process that converts waste into organic manure rich in plant nutrients and humus (Sharma et al 1999). Even though recycling organic waste has been known since biblical times, there are many aspects that should be improved. One of these areas includes reduction in overall time required for composting, especially during the winter season. Various studies have shown that vermicomposting of organic waste accelerates organic matter stabilization (Neuhauser et al 1988; Frederickson et al 1997) and gives a product rich in chelating and phytohormonal elements (Tomati and Galli, 1995) which has a high content of microbial agents and stabilized humic substances (Ferruzi, 1986).

Vermiculture has been receiving considerable attention in recent years internationally for its potential role in organic farming and sustainable development (Kale, 1998). 
Species identified as potentially useful to break down organic wastes were Eisenia fetida, Dendrobaena veneta and Lumbricus rubellus from temperate areas and Eudrilus eugeniae and Perionyx excavatus from the tropics (Edwards, 1998). The survival, growth, mortality and reproduction of these species have been studied thoroughly in the laboratory, using a wide range of organic wastes (Edwards, 1998). Frederickson et al (1997) combined vermiculture with traditional green waste composting systems. Kale and Bano (1986) employed an African earthworm, Eudrilus eugeniae, for degradation of organic wastes. The cast thus obtained was used as bio-organic fertilizer. Goswami and Kalita (2000) showed the efficiency of some indigenous earthworm species of Assam in vermiculture. In India vermiculture is being tested for treatment of agricultural, sugar, food processing wastes (Kale, 2000).

Knowledge about the food requirement and digestive capability of the earthworms is essential to understand the decomposition process during vermicomposting. The enzymes and the enzyme activity in the gut of earthworms and in casts are extremely important since they are responsible for the degradation of organic materials and to make the nutrients in available form for plants. Lee (1985) reported increased enzyme activities and microbial populations in worm casts as compared with the underlying soil. Microorganisms and soil enzymes are closely associated with soil fertility; information on biological characteristics of worm casts can define the importance of worm casting activity in soil fertility. Application of vermicompost to the soil has multitude of advantages such as conservation of energy, increasing the fertilizer use efficiency, improvement of soil properties and enhancement of soil microbial activity. Devi and Prakash (2015) studied the activities of enzymes, amlylase, cellulose, invertase, phosphatase and protease in vermicomposts of three different vermibed substrates. All the enzymes analysed in the study showed higher levels in vermicompost than in composts (control sets without earthworms).

In the present study, the enzymes amylase, cellulase, protease, phosphatase and invertase were analysed from gut contents of three different stages (juvenile, pre-clitellate, clitellate) Perionyx ceylanensis, reared in the vermibed substrates namely, teak leaf litter, paper mill sludge and pressmud in combination with cowdung on $60^{\text {th }}$ day to analyse the different stages of the earthworm and different substrates show any relation.

\section{Materials and Methods}

Teak leaf litter (TLL) was collected from an agroform near Kanchipuram. The paper mill sludge (PMS) was procured from a private mill near Kanchipuram. The filter mud or pressmud (PM) was collected from Cheyyar Co-operative Sugar Mills Ltd., located in Thenthandalam, Anakkayur, Thiruvannamalai District, Tamil Nadu. The cowdung was collected from nearby cattle sheds in fresh form and allowed to stabilize for one week and used for the study. The organic substrates, TLL, PMS and PM were subjected to initial decomposition in rectangular draining cement tanks of $75 \mathrm{~cm} \times 60 \mathrm{~cm} \times 45 \mathrm{~cm}$ size by sprinkling water, regular mixing and turning of the substrates for 20 days. The earthworm, Perionyx ceylanensis Mich. for the study, originally collected from culture bank of the Department of Biology, Gandhigram Rural Institute- Deemed University, Tamil Nadu, India was mass multiplied in cow dung and used for vermicomposting studies. Based on the studies reported by Karmegam and Daniel (2009a and 2009b) and Prakash and Karmegam (2010) on vermicomposting of different organic substrates using $P$. 
ceylanensis, the ratio of organic substrate mix, i.e., 1:1 (50:50) proportion on dry weight basis was used in the present study. Accordingly, the pre-decomposed organic substrates were mixed with cowdung in 1:1 ratio on dry weight basis, transferred to vermibeds and moistened to hold $60-70 \%$ moisture content. The vermicomposting studies were carried out for 60 days using $P$. ceylanensis in three replicates twice under controlled conditions. The enzymes, amylase (EC 3.2.1.1), cellulase (EC 3.2.1.4.), protease (EC 3.4.0), phosphatase (EC 3.1.3.1, 2) and invertase (EC 3.2.1.20) in gut of three different stages (juvenile, pre-clitellate, clitellate) of the earthworm species Perionyx ceylanensis reared in three different substrates were analysed after $60^{\text {th }}$ day. For the enzymatic analysis of worm guts, gut content cleared tissue was used. The activity of amylase, cellulase and invertase was done according to method described by Galstyan (1965). Protease and phosphatase activities were analysed adopting the methods of Sarath et al (1989) and Jannossy (1963), respectively.

\section{Results and Discussion}

The activity of the enzymes, amylase, cellulase, invertase, phosphatase and protease in the gut of different stages of $P$. ceylanensis is given in Tables 1, 2 and 3. As observed from the results of three different substrates, higher activity was shown by clitellate stage of $P$. ceylanensis.

The activity of amylase, $1.11,3.22$ and 7.19 mg glucose/gram of oven dry samples incubated for 24 hours were recorded for juvenile, preclitellate and clitellate $P$. ceylanensis collected from TLL+CD substrate respectively. Similar trend was observed for cellulase, invertase, phosphatase and protease enzymes also (Tables 2 and 3 ).

In all the stages, invertase showed maximum activity when compared with other enzymes studied. The activity of invertase, 4.00, 8.05 and $13.40 \mathrm{mg}$ glucose/gram of oven dry samples incubated for 24 hours were recorded for juvenile, preclitellate and clitellate $P$. ceylanensis collected from $\mathrm{PM}+\mathrm{CD}$ substrate respectively (Table 3 ).

Invariably activity of all the enzymes in preclitellate worms were significantly higher than juveniles $(\mathrm{p}<0.05)$, whereas, the activity of enzymes in clitellate worms showed significantly higher activity than juveniles and preclitellates. The clitellate $P$. ceylanensis collected from $\mathrm{PM}+\mathrm{CD}$ showed 9.00, 10.83, $13.40,10.33$ and $14.67 \mathrm{mg} / \mathrm{g}$ activity of amylase, cellulase, invertase, phosphatase and protease respectively (Table 3 ).

\begin{tabular}{|c|c|c|c|}
\hline \multicolumn{4}{|c|}{$\begin{array}{l}\text { Table.1 Enzyme activities in gut contents of the earthworm, Peryionyx ceylanensis reared } \\
\text { in teak leaf litter + cowdung }(1: 1)\end{array}$} \\
\hline Enzymes analysed & Juvenile & Pre-clitellate & Clitellate \\
\hline Amylase & $1.11^{\mathrm{a}}$ & $3.22^{b}$ & $7.19^{c}$ \\
\hline Cellulase & $1.98^{\mathrm{a}}$ & $4.63^{b}$ & $8.80^{\mathrm{c}}$ \\
\hline Invertase & $2.62^{\mathrm{a}}$ & $5.25^{b}$ & $12.63^{c}$ \\
\hline Phosphatase & $1.30^{\mathrm{a}}$ & $4.17^{b}$ & $9.91^{b}$ \\
\hline Protease & $2.70^{\mathrm{a}}$ & $5.61^{b}$ & $11.33^{c}$ \\
\hline \multicolumn{4}{|c|}{$\begin{array}{l}\text { (Activities of amylase, cellulase and invertase are expressed as } \mathrm{mg} \text { of glucose/g of oven dry samples } \\
\text { for } 24 \mathrm{hrs} \text { of incubation; Protease activity: } \mathrm{mg} \text { of glutamic acid/g of oven dry substrates for } 24 \mathrm{hrs} \text { of } \\
\text { incubation; Phosphatase activity: } \mathrm{mg} / \mathrm{phenol} / \mathrm{g} \text { of oven dry substrates for } 24 \mathrm{hrs} \text { of incubation). }\end{array}$} \\
\hline
\end{tabular}




\begin{tabular}{|l|c|c|c|}
\hline \multicolumn{4}{|c|}{ Table.2 Enzyme activities in gut contents of the earthworm, Peryionyx ceylanensis } \\
reared in paper mill sludge + cowdung (1:1)
\end{tabular}

\begin{tabular}{l}
\hline \multicolumn{4}{|c|}{ Table.3 Enzyme activities in gut contents of the earthworm, Peryionyx ceylanensis } \\
reared in press mud + cowdung (1:1)
\end{tabular}

Comparing the substrates, $\mathrm{PM}+\mathrm{CD}$ showed high activity of the enzymes analysed in the gut. Pressmud (filter cake), a major-by product of sugarcane processing is produced 12 million tones annually (Parthasarathi, 2007). Pressmud is the residue obtained from sedimentation of the suspended materials such as fiber, wax, ash, soil and other particles from the cane juice. Pressmud (filter cake), a major-by product of sugarcane processing has previously been shown to be a substrate suitable for vermicomposting (Parthasarathi and Ranganathan, 2002). The interaction of the microbes and the earthworms contributes to breaking the complex organic compounds in pressmud into simpler forms (Ahmad and Bhargava, 2005).

Earthworms are important in turnover of soil, contribute most to soil invertebrate biomass, contain the highest international units of cellulase and are believed to be capable of producing cellulases and chitinases other than through intestinal microflora (Parle, 1963; Hartenstein, 1981). Cellulases are a group of enzymes that catalyze the degradation of cellulose - a polysaccharide built of $\beta-1,4$ linked glucose units. This group consists of endo 1,4 - glucanase, exo 1,4- glucanase and $\beta$-D-glucosidase. The products of cellulose degradation are glucose, cellobiose and high molecular weight oligosaccharides.

The reasons for more enzyme activities in the casts of E. eugeniae than $P$. excavatus are greater consumption rate, enhanced gut microbial population (Parthasarathi, 1997; Parthasarathi et al 1997; Parthasarathi and Ranganathan, 2002), enhanced microbial population in the casts (Parthasarathi et al 1997) and more moisture. From the results of the study, it is concluded that the enzyme activity in the gut of Perionyx ceylanensis is developmental stage and substrate dependent. 


\section{References}

Ahmad Y, Bhargava R (2005). Vermicomposting of filter mud from sugar industry mixed with food wastes Journal of IAEM, 32(2): 115-121.

Devi, J., Prakash, M., 2015. Nutrient Status, Microflora and Enzyme Activities in Vermicomposts of Three Different Organic Substrates. Int.J.Curr.Res. Aca.Rev.2015; 3(7): 443-448.

Edwards, C.A. 1998. The use of earthworms in the breakdown and management of organic waste. In: Edwards, C.A. (Ed.), Earthworm Ecology. St. Lucie Press, Boca Raton, pp. 327-354.

Ferruzi, C. 1986. Manual de Lombricultura. Ed. Munidiprensa, Madrid.

Frederickson, J., K.R.Butt, R.M.Morris and Daniel, C. 1997. Combining vermiculture with traditional green waste composting systems. Soil Biol. Biochem., 29: 725-730.

Galstyan ASH (1965). Method of determining activity of hydrolytic enzymes of soil. Pochvoved. 2, 68-74.

Goswami, B. \& Kalita, C. (2000). Efficiency of some indigenous earthworm species of Assam and its characterization through vermitechnology. Indian Journal of Environment and Ecoplanning, 3, 351-354.

Hartenstein, R. (1981). Soil macroinvertebrates, aldehyde oxidase, catalase, cellulase and peroxidase. Soil Biol. Biochem., 15, 51-54.

Janossy G (1963) Changes in the phosphatase activity of soil microorganisms in relation to phosphorus supply. Agrok. Talajtan. 12, 285-292.

Kale, R. D. 1998. Earthworms: Nature's gift for utilization of organic wastes In C. A., Edwards (Ed.), Earthworm ecology. Ankeny, Lowa St. Lucie Press, New York. pp. 355-373.

Kale, R.D. 2000. An evaluation of the vermitechnology process for the treatment of agro, sugar and food processing wastes. In: Technology Appreciation Programme on Evalution of Biotechnological Approaches to Waste Management held in 26th October 2000. Industrial AssociationShip of IIT, Madras, pp. 15-17.

Kale, R.D. and Bano, K. 1986. Field trials with vermicompost (Vee. Comp. E. 83 UAS) an organic fertilizer. Proc. Nat. Sem. Organic Waste Utliz., Part B: Verms and Vermicompost. (Ed.: Dash, M.C., B.K. Senapathi and Mishra, P.C.). pp.151-157.

Karmegam, N. and Daniel, T. (2009b). Growth, reproductive biology and life cycle of the vermicomposting earthworm, Perionyx ceylanensis Mich. (Oligochaeta: Megascolecidae). Bioresour. Technol., 100: 4790-4796.

Karmegam, N. and Daniel, T. (2009a). Investigating efficiency of Lampito mauritii (Kinberg) and Perionyx ceylanensis Michaelsen for vermicomposting of different types of organic substrates. Environmentalist, 29: 287-300.

Lee KE (1985) Earthworms - Their Ecology and Relationships with Soils and Land Use, Academic Press, New York, 411 pp.

Neuhauser, E.F., R.C.Loehr and Malecki, M.R. 1988. The potential of earthworms for managing sewage sludge. In: Edwards, C.A., Neuhauser, E.F. (Eds.), Earthworms in Waste and Environmental Management. SPB Academic Publishing, The Hague, pp. 9-20.

Parle, J.N. 1963. Microorganisms in the intestine of earthworms. Journal of General Microbiology, 31: 1-13.

Parthasarathi K (2007) Influence of moisture on the activity of Perionyx excavatus (Perrier) and microbial-nutrient 
dynamics of pressmud vermicompost. Iran. J. Environ. Health Sci. Engg. 4(3), 147-156.

Parthasarathi, K and Ranganathan, L.S. 2002. Supplementation of pressmud vermicasts with NPK enhances growth and yield in leguminous crops (Vignamungo and Arachis hypogaea). Journal of Current Science, 2:35-41.

Parthasarathi, K, L.S.Ranganathan, A. Anandi, and Zeyer, J. 2007. Diversity of microflora in the gut and casts of tropical composting earthworms reared on different susbtrates. J. Environ. Biol., 28(1): 87-97.

Prakash, M. and Karmegam, N. (2010). Vermistabilization of pressmud using
Perionyx ceylanensis Mich. Bioresour. Technol., 101: 8464-8468.

Sarath G, Dela Motte RS, Wagner FW (1989) Proteolytic Enzymes: A Practical Approach, IRL Press, Oxford, England, pp 25-55.

Sharma, S., R.C. Mathur and Vasudevan, P. 1999. Composting silkworm culture waste. Compost Science and Utililization, 7(2): 74-81.

Tomati, U. and Galli, E. 1995. Earthworms, soil fertility and plant productivity. Proceedings of the International Colloquium on Soil Zoology. Acta Zoologica Fennica, 196: 11-14.

\section{How to cite this article:}

Devi J. and Prakash M. 2017. Gut Enzyme Activities of the Earthworm, Perionyx ceylanensis Collected from Different Vermibed Substrates. Int.J.Curr.Microbiol.App.Sci. 6(1): 973-978. doi: http://dx.doi.org/10.20546/ijcmas.2017.601.115 